Plant Genetics

Original Article

\title{
Heterochromatin and numeric chromosome evolution in Bignoniaceae, with emphasis on the Neotropical clade Tabebuia alliance
}

\author{
Joel M. P. Cordeiro ${ }^{1}$ (iD, Miriam Kaehler ${ }^{2}$ (D), Luiz Gustavo Souza ${ }^{2}$ (iD) and Leonardo P. Felix ${ }^{1 *}$ (iD \\ ${ }^{1}$ Universidade Federal da Paraíba, Centro de Ciências Agrárias, Departamento de Ciências Biológicas, \\ Campus II, Areia, PB, Brazil. \\ ${ }^{2}$ Mulleriana: Sociedade Fritz Müller de Ciências Naturais, Curitiba, PR, Brazil. \\ ${ }^{3}$ Universidade Federal de Pernambuco, Centro de Ciências Biológicas, Departamento de Botânica, Recife, \\ PE, Brazil.
}

\begin{abstract}
Bignoniaceae is a diverse family composed of 840 species with Pantropical distribution. The chromosome number $2 n=40$ is predominant in most species of the family, with $n=20$ formerly being considered the haploid base number. We discuss here the haploid base number of Bignoniaceae and examine heterochromatin distributions revealed by CMA/DAPI fluorochromes in the Tabebuia alliance, as well as in some species of the Bignonieae, Tecomeae, and Jacarandeae tribes. When comparing the chromosome records and the phylogenies of Bignoniaceae it can be deduced that the base number of Bignoniaceae is probably $n=18$, followed by an ascendant dysploidy $(n=18 \rightarrow n=$ 20 ) in the most derived and diverse clades. The predominant heterochromatin banding patterns in the Tabebuia alliance were found to be two terminal $\mathrm{CMA}^{+}$bands or two terminal and two proximal $\mathrm{CMA}^{+}$bands. The banding pattern in the Tabebuia alliance clade was more variable than seen in Jacarandeae, but less variable than Bignonieae. Despite the intermediate level of variation observed, heterochromatin banding patterns offer a promising tool for distinguishing species, especially in the morphologically complex genus Handroanthus.
\end{abstract}

Keywords: Chromosome number, CMA/DAPI, Handroanthus, polyploidy.

Received: June 12, 2018; Accepted: March 05, 2019.

\section{Introduction}

Bignoniaceae is a Pantropical family composed mostly of trees and lianas, and includes 82 genera and 840 species (Fischer et al., 2004; Lohmann and Ulloa, 2016). Eight tribes are nested within the family: Bignonieae, Catalpeae, Coleeae, Crescentieae, Jacarandeae, Oroxyleae, Tecomeae, and Tourrettieae, plus the informal Crescentiina clade, that comprises the Neotropical and Palaeotropical subclades (Olmstead et al., 2009). While the morphological features of most tribes of Bignoniaceae are well-characterized, the Crescentiina clade and its subclades are well-sustained lineages, although without clear morphological synapomorphies (Grose and Olmstead, 2007; Olmstead et al., 2009). The Crescentiina clade comprises two informal lineages: the exclusively Neotropical Tabebuia alliance and the Paleotropical clade with Asian and African genera (Olmstead et al., 2009). The Tabebuia alliance has 14 genera and 147 species of trees and shrubs that have composite and palmate leaves (Grose and Olmstead, 2007). Most species within

Send correspondence to Leonardo P. Felix. Universidade Federal da Paraíba, Campus II, Centro de Ciências Agrárias. Rodovia PB 079, Km 12. CEP: 58397-000, Areia, Paraíba, Brazil. E-mail: Ipfelix2@gmail.com. that clade belong to Tabebuia Gomes ex DC. and Handroanthus Mattos, while the remaining genera are smaller but widely-distributed in the Americas (Gentry, 1992; Grose and Olmstead, 2007). There is great morphological variability within the Tabebuia alliance, so that the delimitation of its species is often difficult.

From a cytogenetic point of view, the Bignoniaceae family comprises two groups with distinct karyotypes. The first group has a wide range of chromosome numbers $(2 n=$ $22,28,30,36,38,40$ and 42) and includes the tribes Jacarandeae, Tecomeae, Oroxyleae, and the two genera Argylia D.Don and Delostoma D.Don (Moore, 1974; Goldblatt and Gentry, 1979; Piazzano, 1998; Piazzano et al., 2015). The second group has the prevailing chromosome number $2 n=40$, and includes Bignonieae, Catalpeae, and the Crescentiina clade (Goldblatt and Gentry, 1979; Piazzano, 1998; Alcorcés de Guerra, 2002; Ortolani et al., 2008; Firetti-Leggieri et al., 2011; Piazzano et al., 2015; Cordeiro et al., 2016a, 2017). Ploidy variations ( $2 n=60,80$ and 120) were found for a few species of the tribe Bignonieae and the clade Tabebuia alliance from the second group (Piazzano, 1998; Alves et al., 2013; Piazzano et al., 2015; Cordeiro et al., 2017). 
Most species of Bignoniaceae show $n=20$, and it has been proposed that $x=20$ is the haploid base number for the family (Goldblatt and Gentry, 1979; Piazzano, 1998; Piazzano et al., 2015). However, when confronting the known chromosome numbers of Bignoniaceae and the phylogenetic analyses of Olmstead et al. (2009), it became evident that the most primitive clades (such as Jacarandeae) are $x=$ 18 , suggesting that a different number from 20 could be the haploid base number of the family.

Chromosome numbers and morphologies are the features most used in karyotype analyses and ground cytotaxonomy studies (Guerra, 2008), although those characters can be uninformative in groups where chromosome numbers are stable and the chromosomes are small $(<3$ $\mu \mathrm{m})$ (Guerra, 2000, 2012). Bignoniaceae have chromosome sizes of $\sim 2 \mu \mathrm{m}$, meta- submetacentric morphology, and $2 n=36$ or 40 is predominant in the majority of species (Goldblatt and Gentry, 1979; Piazzano et al., 2015; Cordeiro et al., 2016b, 2017). Banding pattern characterizations can therefore often help discriminate between cytotypes with stable chromosome numbers, sizes and morphologies. The fluorochromes Chromomycin $\mathrm{A}_{3}$ (CMA) and 4'6-diamidino-2-phenylindole (DAPI) are specific for GC-rich (CMA) or AT-rich (DAPI) regions respectively, and usually stain regions with tandem repeats of non-coding DNA (Schweizer, 1976; Guerra, 2000). They have been used mainly to characterize karyotypes with chromosomes that have the same size and morphology, and to differentiate the karyotypes of species with identical chromosome numbers (see Almeida et al., 2007; Barros e Silva et al., 2010; Cordeiro et al., 2016b; Almeida et al., 2016). The different patterns found can help determine taxonomic distinctions and clarify relationships among species (Carvalho et al., 2005; Almeida et al., 2007; Oliveira et al., 2015), as well as contribute to the description of new taxa, such as Epidendrum sanchezii E.Pessoa \& L.P.Felix (Pessoa et al., 2014), Ameroglossum manoel-felixii L.P.Felix \& E.M.Almeida (Almeida et al., 2016), and Spondias bahiensis P.Carvalho, Van den Berg and M.Machado (Almeida et al., 2007; Machado et al., 2015). Preliminary studies in the tribe Jacarandeae (Cordeiro et al., 2016b) indicated that heterochromatin distribution appeared to follow a specific pattern (8-16 $\mathrm{CMA}^{+}$terminal bands), while in the tribe Bignonieae (Cordeiro et al., 2017) heterochromatin distribution is quite variable among the species. That result demonstrates that regions rich in $\mathrm{GC}$ base pairs $\left(\mathrm{CMA}^{+}\right)$can be variable even among closely related species of Bignoniaceae, and that a specific pattern for each group or tribe may not exist.

The main objective of this work was to describe the cytotaxonomic differences between related species of Bignoniaceae (mainly in the Neotropical lineage of the Tabebuia alliance clade) by examining their heterochromatin distributions, and discuss the haploid base number of the
Bignoniaceae based on compilations of the chromosome numbers known for all lineages of the family.

\section{Materials and Methods}

\section{Taxon sampling}

Heterochromatin banding patterns of 12 species of the Tabebuia alliance clade were analyzed (Figure 1), as well as those of three species of Jacarandeae, two species of Tecomeae, and two species of Bignonieae tribes. The species, vouchers, and primarily karyological information are presented in Table 1. The vouchers were deposited in the EAN herbarium. An average of three specimens of each species were grown in plastic pots in the experimental garden of the Centro de Ciências Agrárias of the Universidade Federal da Paraíba. When the roots reached $2 \mathrm{~cm}$ in length, 15 root tips per specimen were excised and analyzed.

\section{Cytogenetic analyses}

Mitosis was examined in root tips that had been pretreated with $0.002 \mathrm{M} 8$-hydroxyquinoline (8-HQ) for $24 \mathrm{~h}$ at $4{ }^{\circ} \mathrm{C}$, fixed in $3: 1(\mathrm{v} / \mathrm{v})$ absolute ethanol/glacial acetic acid for $30 \mathrm{~min}$, and then stored in a freezer at $-20^{\circ} \mathrm{C}$. The roots were digested with an enzymatic solution $(2 \%$ cellulase and $20 \%$ pectinase) for one hour at $37{ }^{\circ} \mathrm{C}$. Root tips were squashed in $45 \%$ acetic acid and coverslips were removed by freezing in liquid nitrogen. The samples were aged for three days at room temperature and stained with 10 $\mu \mathrm{L}$ of CMA $(0.1 \mathrm{mg} / \mathrm{mL})$ for $1 \mathrm{~h}$, and then with $10 \mu \mathrm{L}$ of DAPI $(1 \mu \mathrm{g} / \mathrm{mL})$ for $30 \mathrm{~min}$. The samples were mounted in glycerol/McIlvaine's buffer at $\mathrm{pH} 7.0(1: 1, \mathrm{v} / \mathrm{v})$ and kept in the dark for three days (Cordeiro et al., 2017).

The best metaphases were photographed using an AxioCam MRC5 digital camera and AxioVision 4.8 software (Carl Zeiss Microscopy GmbH, Jena Germany). Measurements were made using Uthscsa Image Tool (IT) v 3.0 software. The final images were prepared using Adobe Photoshop CS3 v 10.0 (Adobe Systems Incorporated, San Jose, USA). Chromosome morphology was determined using the centromeric index, following Guerra (1986).

\section{Base chromosome number and karyotype evolution}

The base chromosome number analysis is based on 179 species of Bignoniaceae, distributed in all of the clades retrieved by Olmstead et al. (2009) for the family. The list of samples, and their chromosome numbers and respective references are presented in Table S1 (Supplementary Material). Karyotype and molecular phylogenetic data were compiled for representatives of the Bignoniaceae. The numbers of species analyzed in each Bignoniaceae clade and their chromosome numbers and frequencies are presented in a phylogeny adapted from Olmstead et al. (2009) to demonstrate their putative chromosome number evolution. Information concerning heterochromatin patterns is presented for Bignonieae, Tabebuia alliance, Tecomeae, 

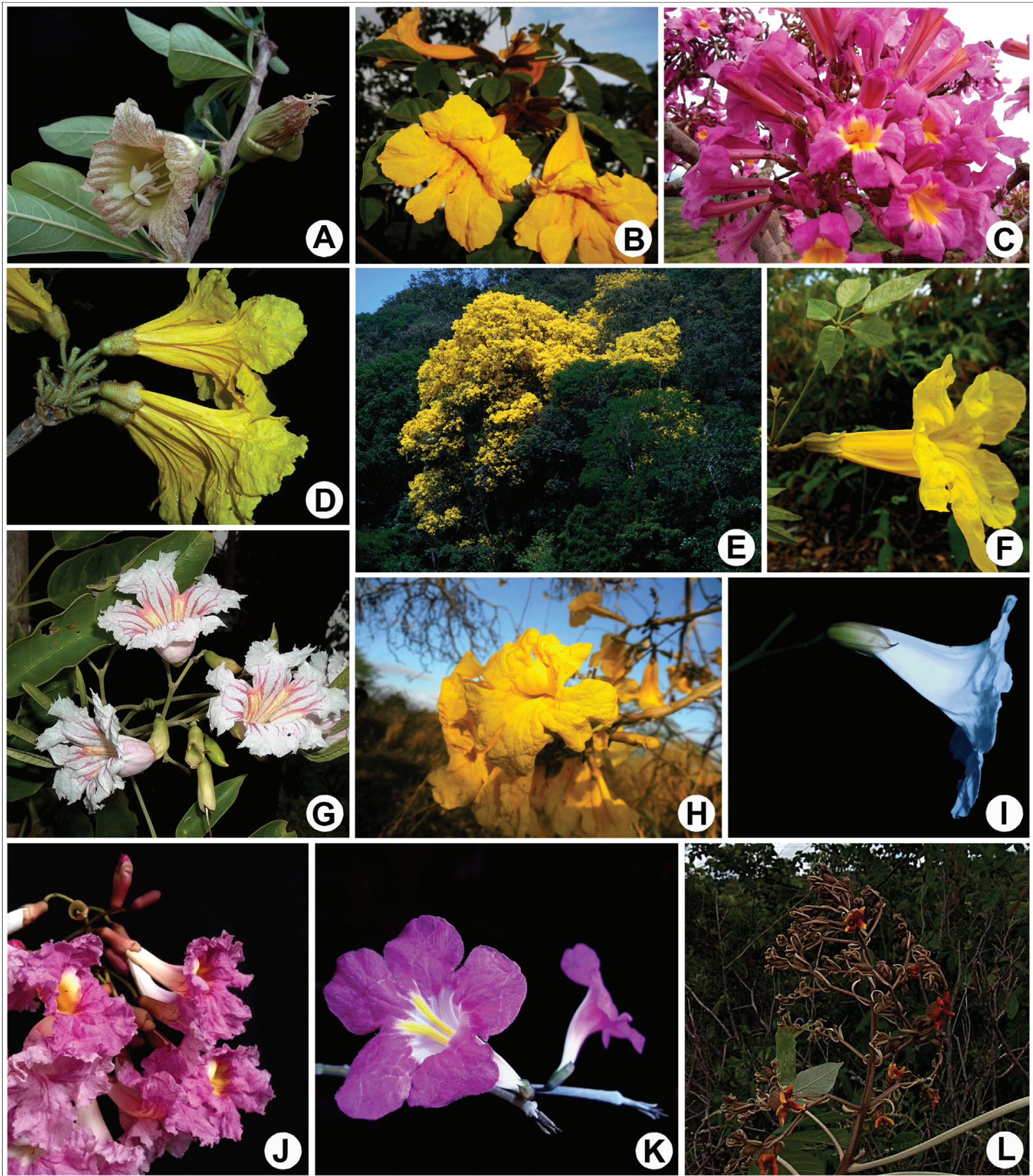

Figure 1 - Some of the species of the Neotropical lineage Tabebuia alliance clade sampled. A. Crescentia cujete, B. Handroanthus chrysotrichus, C. H. impetiginosus, D. H. ochraceus, E. H. serratifolius, F. H. umbellatus, G. Sparattosperma leucanthum, H. Tabebuia aurea, I. T. elliptica, J. T. rosea, K. T. roseoalba, L. Zeyheria tuberculosa.

and Jacarandeae. The chromosomes types (A, B, C, D, E and F) follow Cordeiro et al. (2017).

\section{Results}

\section{Chromosome numbers}

The chromosome number of 12 species of the Tabebuia alliance clade was analyzed, as well as those of three species of Jacarandeae, two species of Tecomeae, and two species of Bignonieae tribes. The karyotypes of the 19 species analyzed were predominantly symmetrical, principally with metacentric or sub-metacentric chromosomes. Their sizes ranged from $1.02 \mu \mathrm{m} \pm 0.13$ in Tabebuia aurea (Silva Manso) Benth. \& Hook. f. ex S. Moore to $2.19 \mu \mathrm{m} \pm 0.3$ in J. praetermissa. The chromosome number of most of the 
Table 1 - Species of Bignoniaceae analyzed and their main karyological parameters. Heterochromatin patterns: A - large telomeric CMA ${ }^{+}$bands, B small telomeric $\mathrm{CMA}^{+}$bands, $\mathrm{C}$ - proximal CMA ${ }^{+}$bands, $\mathrm{F}$ - lack of heterochromatic bands. Abbreviations of the Voucher: JMPC - Joel Maciel Pereira Cordeiro, LPF - Leonardo Pessoa Felix, EMA - Erton Mendonça de Almeida, SAAL - Saulo Antonio Alves de Lima. Abbreviations in the Origin: PB Paraíba State, BA - Bahia State, PI - Piauí State, and MG - Minas Gerais State, Brazil.

\begin{tabular}{|c|c|c|c|c|c|c|}
\hline Tribe/Alliance/species & Voucher & Origin & $2 n$ & Median size $(\mu \mathrm{m})$ & $\begin{array}{c}\text { Heterochromatin } \\
\text { patterns }\end{array}$ & Figure \\
\hline \multicolumn{7}{|l|}{ Jacarandeae } \\
\hline Jacaranda jasminoides (Thunb.) Sandwith. & JMPC, 131 & Sertãozinho-PB & 36 & 2.09 & $6 \mathrm{~A}+4 \mathrm{~B}+26 \mathrm{~F}$ & $3 \mathrm{~A}$ \\
\hline J. mimosifolia D.Don & LPF, 14457 & Areia-PB & 36 & 1.84 & $6 \mathrm{~A}+2 \mathrm{~B}+28 \mathrm{~F}$ & $3 \mathrm{~B}$ \\
\hline J. praetermissa Sandwith* & LPF, 17606 & $\begin{array}{l}\text { Serra da } \\
\text { Capivara-PI }\end{array}$ & 36 & 2.19 & $2 \mathrm{~A}+8 \mathrm{~B}+26 \mathrm{~F}$ & $3 \mathrm{C}$ \\
\hline \multicolumn{7}{|l|}{ Tecomeae } \\
\hline Podranea ricasoliana (Tanfani) Sprague & JMPC, 135 & Areia-PB & 38 & 1.07 & $6 \mathrm{~B}+32 \mathrm{~F}$ & $3 \mathrm{D}$ \\
\hline Tecoma stans (L.) Juss. ex Kunth & LPF, 14412 & Paulo Afonso-BA & 36 & 1.16 & $2 \mathrm{~A}+4 \mathrm{C}+30 \mathrm{~F}$ & $3 \mathrm{E}$ \\
\hline \multicolumn{7}{|l|}{ Bignonieae } \\
\hline Anemopaegma citrinum Mart. ex DC.** & JMPC, 1254 & Pico do Jabre-PB & 40 & 1.32 & $\begin{array}{c}2 \mathrm{~A}+2 \mathrm{~B}+2 \mathrm{D}+ \\
34 \mathrm{~F}\end{array}$ & $3 \mathrm{~F}$ \\
\hline Fridericia chica (Bonpl.) L.G.Lohmann* & & Manaus, AM & 40 & 1.76 & $\begin{array}{c}6 \mathrm{~A}+26 \mathrm{~B}+6 \mathrm{E}+ \\
2 \mathrm{~F}\end{array}$ & $3 \mathrm{G}$ \\
\hline \multicolumn{7}{|l|}{ Tabebuia alliance } \\
\hline Handroanthus chrysotrichus (Mart. ex DC.) & EMA, 814 & $\begin{array}{l}\text { Campina } \\
\text { Grande-PB }\end{array}$ & 80 & 1.44 & $\begin{array}{c}4 \mathrm{~A}+4 \mathrm{~B}+4 \mathrm{C}+ \\
68 \mathrm{~F}\end{array}$ & $1 \mathrm{~B}, 3 \mathrm{H}$ \\
\hline H. impetiginosus (Mart. ex DC.) Mattos & SAAL, 86 & Areia-PB & 40 & 1.39 & $2 \mathrm{~A}+2 \mathrm{C}+36 \mathrm{~F}$ & $1 \mathrm{C}, 3 \mathrm{I}$ \\
\hline H. ochraceus (Cham.) Mattos & SAAL, 84 & João Pessoa-PB & 80 & 1.42 & $6 \mathrm{~B}+74 \mathrm{~F}$ & $1 \mathrm{D}, 3 \mathrm{~J}$ \\
\hline H. serratifolius (Vahl.) S. O. Grose. Mattos & JMPC, 251 & Areia-PB & 120 & 1.63 & $\begin{array}{c}4 \mathrm{~A}+6 \mathrm{~B}+4 \mathrm{C}+ \\
106 \mathrm{~F}\end{array}$ & $1 \mathrm{E}, 4 \mathrm{~A}$ \\
\hline H. umbellatus (Sond.) Mattos* & JMPC, 1043 & Sertãozinho-PB & 40 & 1.66 & $\begin{array}{c}2 \mathrm{~A}+\underset{32 \mathrm{~F}}{2 \mathrm{~B}}+4 \mathrm{C}+ \\
\end{array}$ & $1 \mathrm{~F}, 4 \mathrm{~B}$ \\
\hline $\begin{array}{l}\text { Sparattosperma leucanthum (Vell.) } \\
\text { K.Schum.* }\end{array}$ & LPF, 15402 & $\begin{array}{l}\text { Alvorada de } \\
\text { Minas-MG }\end{array}$ & 40 & 1.55 & $2 \mathrm{~A}+38 \mathrm{~F}$ & $1 \mathrm{G}, 4 \mathrm{C}$ \\
\hline $\begin{array}{l}\text { Tabebuia aurea (Silva Manso) Benth. \& } \\
\text { Hook.f. ex S. Moore }\end{array}$ & JMPC, 1078 & Pirpirituba-PB & 40 & 1.02 & $2 \mathrm{~A}+38 \mathrm{~F}$ & $1 \mathrm{H}, 4 \mathrm{D}$ \\
\hline T. elliptica (DC.) Sandwith* & SAAL, 81 & Santa Rita-PB & 40 & 1.86 & $2 \mathrm{~A}+38 \mathrm{~F}$ & $1 \mathrm{I}, 4 \mathrm{E}$ \\
\hline T. rosea (Bertol.) Bertero ex A. DC. & JMPC, 154 & Areia-PB & 40 & 1.51 & $2 \mathrm{~A}+2 \mathrm{C}+36 \mathrm{~F}$ & $1 \mathrm{~J}, 4 \mathrm{~F}$ \\
\hline T. roseoalba (Ridl.) Sandwith* & LPF, 14590 & $\begin{array}{l}\text { Campina } \\
\text { Grande-PB }\end{array}$ & 40 & 1.67 & $2 \mathrm{~A}+2 \mathrm{C}+36 \mathrm{~F}$ & $1 \mathrm{~K}, 4 \mathrm{G}$ \\
\hline $\begin{array}{l}\text { Zeyheria tuberculosa (Vell.) Bureau ex } \\
\text { Verl.* }\end{array}$ & LPF, 14468 & Maracás-BA & 40 & 1.85 & $2 \mathrm{~A}+2 \mathrm{C}+36 \mathrm{~F}$ & $1 \mathrm{~L}, 4 \mathrm{H}$ \\
\hline \multicolumn{7}{|l|}{ Crescentieae } \\
\hline Crescentia cujete L. & JMPC, 137 & Serra da Raiz-PB & 40 & 1.21 & $2 \mathrm{~A}+38 \mathrm{~F}$ & $1 \mathrm{~A}, 4 \mathrm{I}$ \\
\hline
\end{tabular}

* First chromosome count for the species.

**New cytotype for the species.

Tabebuia alliance was $2 n=40$ (Crescentia L., Sparattosperma Mart. ex Meisner, Tabebuia Gomez, and Zeyheria Mart.). However, Handroanthus Mattos showed $2 n=$ 40 [H. impetiginosus (Mart. ex DC.) Mattos and H. umbellatus] as well as $2 n=80$ [H. chrysotrichus (Mart. ex DC.) Mattos and H. ochraceus (Cham.) Mattos], and $2 n=120$ [H. serratifolius (Vahl.) S.O.Grose]. The remaining species showed $2 n=36$ [Jacaranda mimosifolia D.Don., J. jasminoides (Thunb.) Sandwith., J. praetermissa, and Tecoma stans (L.) Juss. ex Kunth], $2 n=38$ [Podranea ricasoliana
(Tafani) Sprague], or $2 n=40$ (A. citrinum and $F$. chica) (Table 1).

New chromosome records are described for Handroanthus umbellatus (Sond.) Mattos, Sparattosperma leucanthum (Vell.) K.Schum, Tabebuia elliptica (DC.) Sandwith, T. roseoalba (Ridl.) Sand., and Z. tuberculosa (Vell.) Bureau ex Verl. ( $2 n=40$; Tabebuia alliance), as well as for Fridericia chica (Bonpl.) L.G.Lohmann ( $2 n=40$; Bignonieae tribe) and Jacaranda praetermissa Sandwith $(2 n=$ 36 ; Jacarandeae tribe). Additionally, a new cytotype is de- 
scribed for Anemopaegma citrinum Mart. ex DC. $(2 n=40$; Bignonieae tribe).

\section{Base chromosome number and karyotype evolution}

The chromosome numbers of 179 species of Bignoniaceae (belonging to all of its clades) were compared (Table S1). Overall, most species showed $2 n=40(67 \%)$ and $2 n=36(19 \%)$. Chromosome numbers were compiled in a phylogeny adapted from Olmstead et al. (2009) to infer chromosome number evolution (Figure 2). The chromosome number $2 n=36(n=18)$ was principally distributed within the tribe Jacarandeae, while $2 n=40(n=20)$ appeared especially in the tribes Bignonieae and Catalpeae, in the clade Crescentiina, and in Tourrettieae. Other chromosome numbers occurred in Argylia $(2 n=30)$ and Delostoma $(2 n=42)$, and in the tribes Oroxyleae $(2 n=28$ and 30$)$ and Tecomeae $(2 n=22,38$ and 48$)$.

\section{Heterochromatin patterns}

The heterochromatin banding patterns of the 19 species analyzed showed GC-rich $\left(\mathrm{CMA}^{+} / \mathrm{DAPI}^{-}\right)$bands located on the telomeric or proximal regions of the chromosomes (Figures 3 and 4). The species belonging to Jacarandeae, Tecomeae, and Bignonieae tribes had distinct patterns of $\mathrm{CMA}^{+} / \mathrm{DAPI}^{-}$bands. Jacarandeae had five pairs of telomeric bands in $J$. jasminoides (Figure 3A) and $J$. praetermissa (Figure 3C), and four telomeric pairs in $J$. mimosifolia (Figure 3B). Tecomeae had three pairs of inconspicuous telomeric bands in P. ricasoliana (Figure 3D), and one telomeric pair plus two proximal pairs in $T$. stans (Figure 3E). Bignonieae displayed two telomeric pairs as well as two telomeric and proximal pairs in A. citrinum (Figure $3 \mathrm{~F}$ ), and 16 telomeric pairs and three telomeric

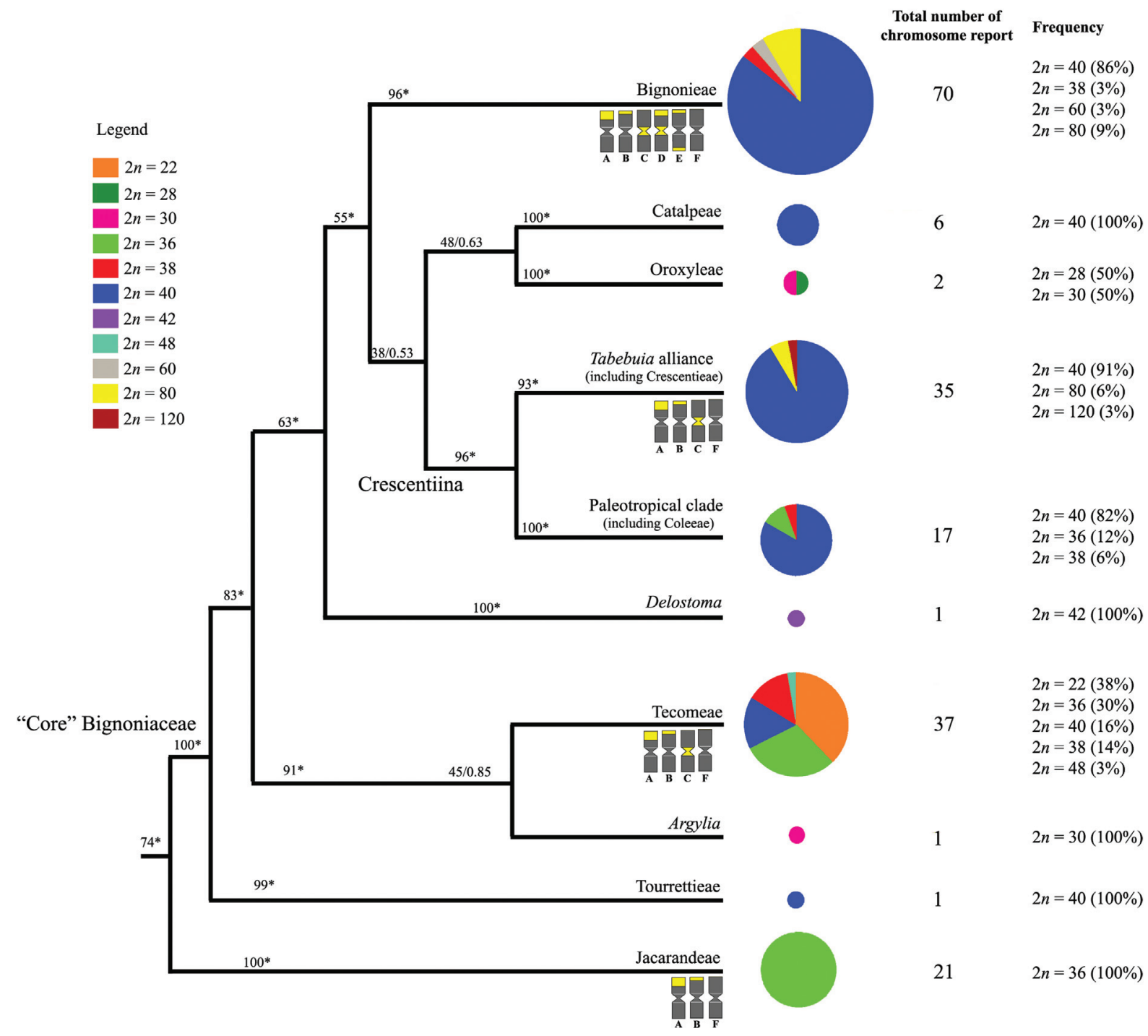

Figure 2 - Chromosome numbers of the Bignoniaceae clades. Values on the branches indicate bootstrap parsimony analysis and the posterior probability of Bayesian inference; Asterisks indicate 100\% posterior probabilities (topology and support values following Olmstead et al., 2009). Circle sizes correspond to the numbers of species with chromosome records in each clade. Chromosomes types A, B, C, D, E and F follow Cordeiro et al. (2017). 


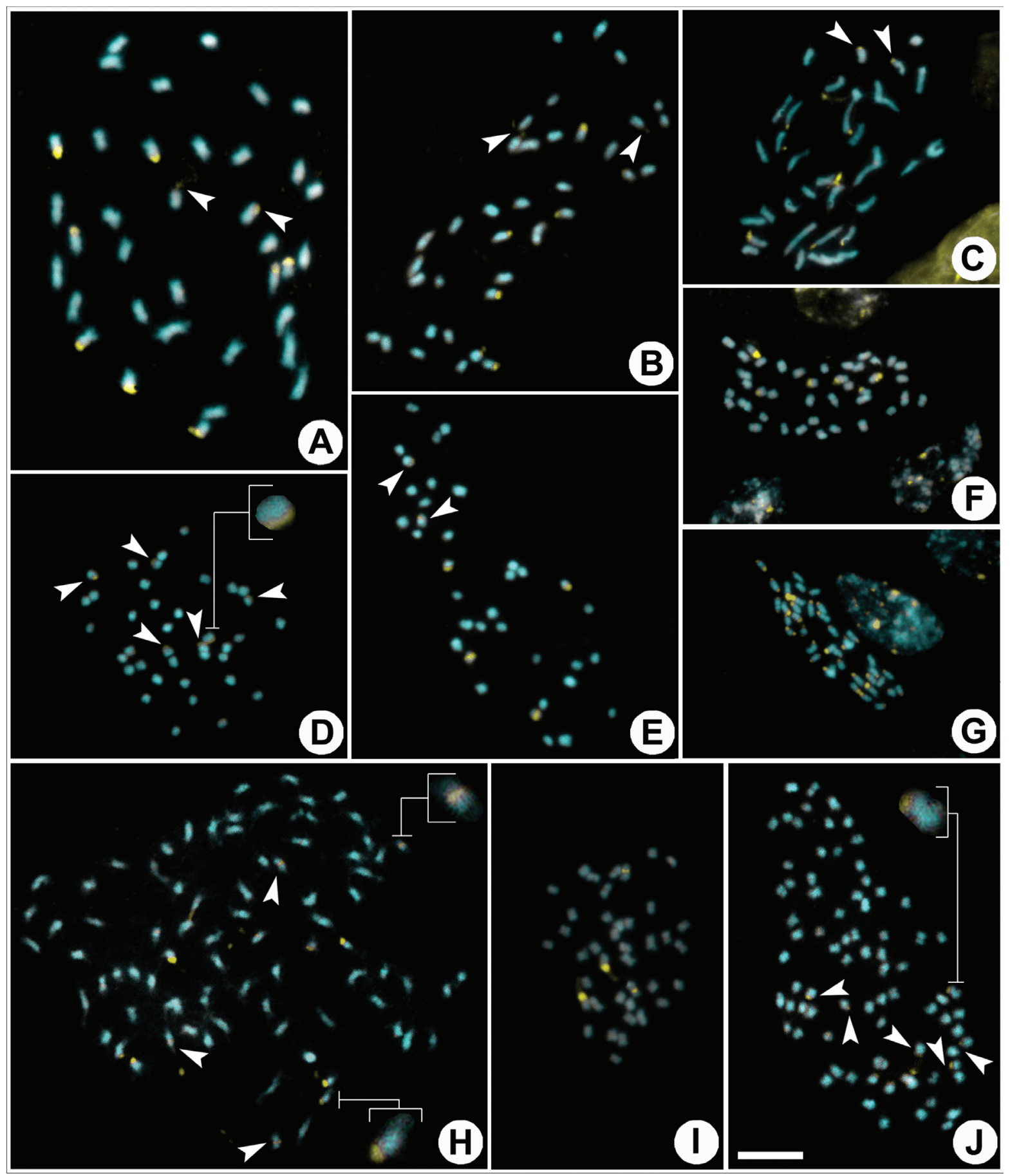

Figure 3 - Distribution of heterochromatic bands ( $\mathrm{CMA}^{+}$, in yellow) of species of Jaracandeae, Tecomeae, Bignonieae and the Tabebuia alliance. A. Jacaranda jasminoides $(2 n=36)$, B. J. mimosifolia $(2 n=36)$, C. J. praetermissa $(2 n=36)$, D. Podranea ricasoliana $(2 n=38)$, E. Tecoma stans $(2 n=36)$, F. Anemopaegma citrinum $(2 n=40)$, G. Fridericia chica $(2 n=40)$, H. Handroanthus chrysotrichus $(2 n=80)$, I. H. impetiginosus $(2 n=40)$, J. H. ochraceus $(2 n=80)$. Scale bar in J corresponds to $10 \mu \mathrm{m}$. Arrow heads indicate minor CMA bands; inserts in D, H and J highlight chromosomes with inconspicuous CMA bands.

pairs with bands on the short and long arm in F. chica (Figure $3 \mathrm{G})$.

Most species in the Tabebuia alliance had karyotypes with a pair of chromosomes with large $\mathrm{CMA}^{+} / \mathrm{DAPI}^{-}$telomeric bands, as seen in Crescentia cujete L. (Figure 4I), S. leucanthum (Figure 4C), T. elliptica (Figure 4E), and T. aurea (Figure 4D). Karyotypes with two telomeric and two proximal bands were observed in H. impetiginosus (Figure 3I), Tabebuia rosea (Bertol.) Bertero ex A.DC. (Figure 4F), T. roseoalba (Figure 4G), and Z. tuberculosa (Figure 4H). The remaining species of Handroanthus showed distinct heterochromatin patterns: four telomeric bands (two large 


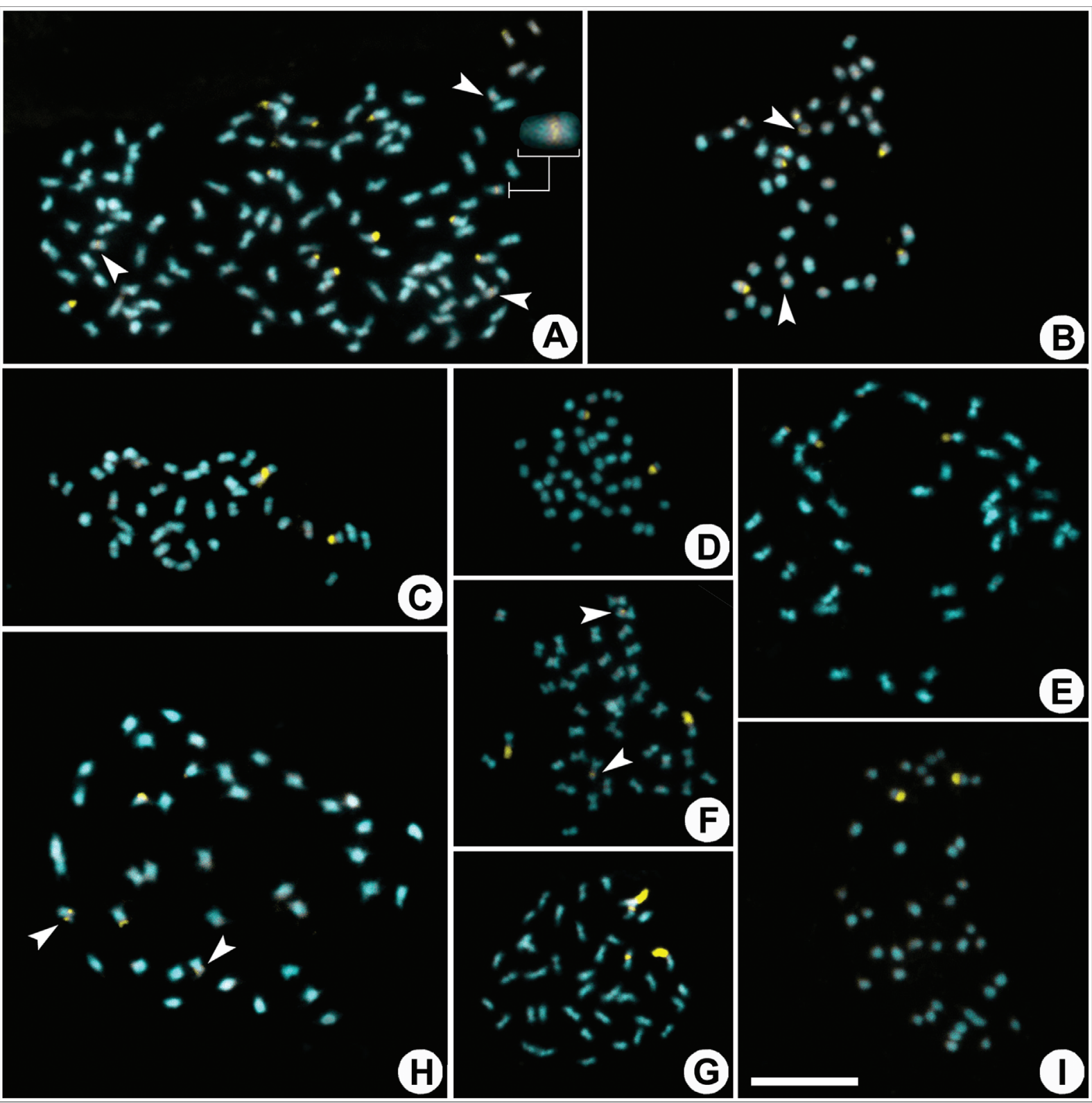

Figure 4 - Distribution of heterochromatic bands ( $\mathrm{CMA}^{+}$, in yellow) of species of the Tabebuia alliance (including Crescentieae). A. Handroanthus serratifolius $(2 n=120)$, B. H. umbellatus $(2 n=40)$, C. Sparattosperma leucanthum $(2 n=40)$, D. Tabebuia aurea $(2 n=40)$, E. T. elliptica $(2 n=40)$, F. T. rosea $(2 n=40)$, G. T. roseoalba $(2 n=40)$, H. Zeyheria tuberculosa $(2 n=40)$, I. Crescentia cujete $(2 n=40)$. Scale bar in I corresponds to $10 \mu \mathrm{m}$. Arrow heads indicate minor CMA bands; inserts in A highlight chromosomes with inconspicuous CMA bands.

and two small) and four proximal bands in H. umbellatus (Figure 4B), four small telomeric bands in H. ochraceus (Figure 3J), eight telomeric bands (four large and four small) and four proximal bands in H. chrysotrichus (Figure $3 \mathrm{H}$ ), and ten telomeric bands (four large and six small) and four proximal bands in H. serratifolius (Figure 4A).

\section{Discussion}

\section{Chromosome number evolution in Bignoniaceae}

Raven (1975) suggested $x=7$ as the ancestral base number for Bignoniaceae, with the most common $n=20$ being generated by a six-fold polyploidization followed by the loss of one pair of chromosomes; that base number was suggested because he considered Oroxyleae ( $n=14$ and 15) to be the most primitive tribe in Bignoniaceae. Several cytological studies in Bignoniaceae (Goldblatt and Gentry, 1979; Piazzano, 1998; Chen et al., 2004) agreed with the hypothesis of Raven (1975). More recent works, such as Piazzano et al. (2015), however, suggested $x=20$ as the basic number of Bignoniaceae. The principal justification for that would be the large number of species with $2 n=40$, and groups considered correlated with Bignoniaceae, such as 
Paulowniaceae and Schlegeliaceae, which also share the haploid number $n=20$.

Molecular phylogeny, however, suggests a different story. Paulowniaceae and Schlegeliaceae are not closely related to Bignoniaceae (Olmstead et al., 2009; RefulioRodriguez and Olmstead, 2014). According to Olmstead et al. (2009), the first diverging lineage within Bignoniaceae was Jacarandeae $(2 n=36)$, followed by a strongly supported clade (core Bignoniaceae) with Tourrettieae $(2 n=$ $40)$, and then Argylia $(2 n=30)$, Tecomeae $(2 n=18,22,34$, 36,38 , and 40), and a large clade including Oroxyleae $(2 n=$ 28,30 ), Crescentiina (mostly $2 n=40$, but also $36,38,80$ and 120), and Bignonieae (mostly $2 n=40$, but also 38, 60 , and 80) (Figure 2). Among the most basal lineages (Jacarandeae, Tourrettieae, Argylia, Tecomeae, and Delostoma) only $8.7 \%$ of the species (five species) have $2 n=40$, whereas $56.1 \%$ (32 species) show $2 n=36$ (Table S1, Figure 2). Consequently, the haploid base number for the family is $x \neq 20$. Very likely, the haploid number is $x=18$, which was followed by an ascendant dysploidy $(n=18 \rightarrow n=20)$ in the most derived and diversified clades of the family.

Jacarandeae and Tourretieae are the most primitive group for Bignoniaceae. Jacarandeae include two genera (Jacaranda Juss. and Digomphia Benth.) and approximately 55 species that are widely distributed throughout the Neotropics (Gentry, 1980; Olmstead et al., 2009). The chromosome number in the Jacaranda is very well characterized by the $2 n=36$ (Cordeiro et al., 2016b). Tourrettieae include two small genera subwoody to herbaceous vines (Eccremocarpus Ruiz \& Pav. and Tourrettia DC.) and six species distributed in the Andes and north in the Central American Cordilleras to Mexico (Gentry, 1980; Olmstead et al., 2009). There are chromosomal records in this tribe only for Tourrettia lappacea (L'Hér.) Willd. $(2 n=40)$ (Goldblatt and Gentry, 1979). Although the chromosomal record for Tourrettieae and Jacarandeae are different, these two basal tribes share some traits, as the doubly compound leaves and pollen that is psilate and tricolpate (Olmstead et al., 2009). Further sampling in Tourrettieae can confirm whether $2 n=40$ is a typical chromosomal number for the tribe species or if there may be other chromosome numbers, as also observed in Tecomeae.

Tecomae is placed between the basal (Jacarandeae and Tourrettieae) and most derived clades of the Bignoniaceae (Crescentiina, Bignonieae, Catalpeae). The tribe is characterized by wide variations in chromosome numbers $(2 n=22,36,38,40$, and 48), unlike other tribes where $2 n=$ 36 (Jacarandeae) or $2 n=40$ (Bignonieae, Catalpeae, and Crescentiina clade) predominate (Table S1, Figure 2). Variations in chromosome numbers in Tecomeae represent events of ascending and descending disploidy resulting in different chromosome numbers. The presence of $n=20$ in Tourrettieae suggests that this number could have arisen at the Core Bignoniaceae by ascending disploidy, while the other numbers could have arisen by ascending $(n=21,24)$ and descending $(n=11,14,15,19)$ disploidy.

Most species of the derived clade comprising Catalpeae, Oroxyleae, Crescentiina, and Bignonieae (Olmstead et al., 2009) have the karyotype $2 n=40$. Among the 122 species with known chromosome numbers within this clade, $92.6 \%$ (113 species) show $2 n=40$. Only six species show $2 n \neq 40$ [two species of Mansoa DC. in Bignonieae, two species of Oroxyleae, and Spathodea campanulata P. Beauv. and Radermacheraxylocarpa (Roxb.) Roxb. ex K. Schum.; Table S1]. The remaining species are polyploids of the haplotype $n=20(2 n=60,80,120)$. This large clade comprises around $80 \%$ of the species of Bignoniaceae (Olmstead et al., 2009), which makes $2 n=40$ the most common karyotype in the family. The four tribes and informal groups in this derived clade show marked geographical patterns. The most species-rich tribe (Bignonieae) is Neotropical (Fischer et al., 2004) as is one lineage of the informal Crescetiina (which also has one Paleotropical clade) (Grose and Olmstead, 2007). Catalpeae is from temperate North America and China and the tropical Greater Antilles (Gentry, 1980; Olsen and Kirkbride Jr, 2017), while the smallest tribe, Oroxyleae, is from tropical southern and southeastern Asia and Malaysia (Olmstead, 2013). Their wide distribution around the world and the high numbers of species in those tribes make $n=20$ the most common haploid number in Bignoniaceae. The haploid number $n=20$ could be related to actual diversity and the occupation of a wide variety of habitats.

Reported chromosome numbers suggest that polyploidy is restricted to the clades Tabebuia alliance and Bignonieae (Goldblatt and Gentry, 1979; Piazzano, 1998; Firetti-Leggieri et al., 2011, 2013; Cordeiro et al., 2017). Reproductive analyses of Handroanthus and Anemopaegma Mart. ex Meisn. indicated self-pollination, sporophytic and pseudogamous apomixis, and polyembryonic seeds (Piazzano, 1998; Bittencourt Jr and Moraes, 2010; FirettiLeggierri et al., 2013) - which are common features in polyploid species (Piazzano, 1998; Firetti-Leggieri et al., 2013). Piazzano et al. (2015) suggested that the polyploidy observed in those species probably originated by meiotic alteration, leading to the production of non-reduced gametes. The absence of a morphological continuum between sympatric species of the same genera (personal observations) suggests an autopolyploid origin.

\section{Heterochromatin patterns}

Heterochromatin in the basal lineage of Jacarandeae (Bignoniaceae) is composed exclusively by $8-16$ terminal $\mathrm{CMA}^{+}$bands, while the following lineages (Tecomeae, Bignonieae, Tabebuia alliance) also demonstrate pericentromeric $\mathrm{CMA}^{+}$bands, but with reductions in the numbers of terminal $\mathrm{CMA}^{+}$blocks (Cordeiro et al., 2016b, 2017; Figures 3 and 4). In certain plant groups, such as the Caesalpinia group (Van-Lume et al., 2017), and sect. Acan- 
thophora of Solanum L. (Chiarini et al., 2014) and Nierembergia Ruiz \& Pav. (Acosta et al., 2016), the heterochromatin patterns appear to follow a specific evolutionary pattern for the species in the different clades. In genera such as Lycium L. (Stiefkens et al., 2010), Pereskia Mill. (Castro et al., 2016), and Ceiba Mill. (Figueredo et al., 2016), however, the heterochromatin pattern appears to be quite conserved and demonstrate only small variability among the different species. In most plant groups, however, heterochromatin patterns tend to be random and quite distinct, even among closely related species (Berjano et al., 2009; Scaldaferro et al., 2012; Grabiele et al., 2018; Van-Lume and Souza, 2018). For Bignoniaceae as a whole, three heterochromatin patterns can be seen, with the occurrence of a specific pattern for Jacarandeae (terminal $\mathrm{CMA}^{+}$ blocks), conserved patterns for the diploid species of the Tabebuia alliance (two terminal $\mathrm{CMA}^{+}$blocks and 0-2 pericentromeric $\mathrm{CMA}^{+}$blocks), and a pattern of random attributions in relation to the numbers and positions of $\mathrm{CMA}^{+}$ blocks in the tribe Binonieae (Cordeiro et al., 2017).

The heterochromatin banding patterns of the Bignonieae tribe in Bignoniaceae (Cordeiro et al., 2017) are characterized by strong differences in the sizes and locations of the $\mathrm{CMA}^{+}$blocks, and six chromosome types are recognized based on heterochromatic regions. The two species of Bignonieae analyzed here confirm the patterns described before for the tribe, with the occurrence of type A (large telomeric $\mathrm{CMA}^{+}$bands), type $\mathrm{B}$ (small telomeric $\mathrm{CMA}^{+}$bands), type $\mathrm{D}$ (telomeric and proximal $\mathrm{CMA}^{+}$ bands), and type $\mathrm{F}$ chromosomes (showing a lack of heterochromatic bands) in A. citrinum, and type A, B, E (two telomeric $\mathrm{CMA}^{+}$bands) and $\mathrm{F}$ chromosomes in $F$. chica (Table 1, Figure 2). The species sampled in Tabebuia alliance, Jacarandeae, and Tecomeae have four chromosome types (according to Cordeiro et al., 2017): type A, type B, type $\mathrm{C}$ (proximal $\mathrm{CMA}^{+}$bands), and type $\mathrm{F}$.

The pattern of two $\mathrm{CMA}^{+}$telomeric bands (chromosome type A) seen in most species of the Tabebuia alliance is very common among Angiosperms, and usually corresponds to a nucleolar organizer region (Guerra, 2000; Roa and Guerra, 2012). Telomeric CMA bands are most likely related to rDNA sites as seen in most plant species (Barros e Silva et al., 2010; Castro et al., 2016; Marinho et al., 2018). Differences among species could be related tochromosome rearrangements and the amplification and reduction of rDNA sites caused by satellites or transposable sequences (Mehrotra and Goyal, 2014; Evtushenko et al., 2016; Saze, 2018).

The vegetative morphologies of Handroanthus species having yellow corollas are very similar (Gentry, 1992), with $H$. chrysotrichus and $H$. ochraceus being very close, even when comparing their flowers, leaves, and fruits. Those two species show a continuum of morphological variations, and hybridization or introgression has therefore been suggested (Gentry, 1992; Bittencourt Jr and Moraes,
2010). However these species have a distinctive heterochromatin banding pattern $4 \mathrm{~A}+4 \mathrm{~B}+4 \mathrm{C}$ in $H$. chrysotrichus and 4B in $H$. ochraceus. Similarly, $T$. roseoalba and T. elliptica have very similar flowers and fruits, although they can be differentiated by their 3- or 5 -foliolate leaves respectively (Gentry, 1992). The heterochromatin banding patterns of those two species are distinct, with the former having two proximal plus two telomeric bands $(2 \mathrm{~A}+2 \mathrm{C})$, while the latter has only two telomeric bands (2A). While banding patterns are still seldom-used in taxonomic studies, the results reported here support their utility in such analyses.

The chromosome numbers and heterochromatin banding patterns of $J$. jasminoides, $J$. praetermissa and $J$. mimosifolia support published data for the genus (Cordeiro et al., 2016b). Jacaranda is one of the largest genera of Bignoniaceae, with more than 50 species widely distributed in the Neotropics (Gentry and Morawetz, 1992). The genus is very well characterized by the chromosome number $2 n=$ 36 (Morawetz, 1982; Cordeiro et al., 2016b) and by having 8 to 16 small and terminal $\mathrm{CMA}^{+}$bands (Cordeiro et al., 2016b). In addition to its stable chromosome features, Jacaranda has a very consistent morphology, with all of its species having pinnate or bipinnate leaves, calyx lobes that are deeply divided, staminodes longer than the stamens, and oblong and strongly flattened capsules opening through a rupture perpendicular to the septum (Morawetz, 1982; Gentry and Morawetz, 1992; Olmstead et al., 2009).

The heterochromatin banding patterns of Tecomeae have been poorly studied. The karyotypes of the two species of the tribe analyzed here, however, were relatively distinct from the species belonging to Jacarandeae, the Tabebuia alliance clades, and Bignonieae species (Cordeiro et al., 2017). Although $T$. stans shows $2 n=36$, its heterochromatin banding pattern $(2 \mathrm{~A}+4 \mathrm{C})$ is quite distinct from species with similar chromosome numbers, such as Jacaranda (8-16 A + B; Cordeiro et al., 2016b). Regarding P. ricasoliana, this species has an uncommon chromosome number for the Bignoniaceae $(2 n=38)$ and six small terminal $\mathrm{CMA}^{+}$bands - a unique pattern in the family (which usually has at least two large terminal $\mathrm{CMA}^{+}$bands) (Cordeiro et al., 2016b, 2017). Although there is still little data available concerning banding patterns in Tecomeae, their lack of synapomorphies (Olmstead et al., 2009), wide distributions (Olmstead, 2013), high variability of life forms (including herbs, shrubs, trees, and lianas), environments occupied (from tropical to temperate forests, to both Andean and Himalayan mountains), and variations in chromosome numbers of the species within this clade, make this tribe one of the major challenges in Bignoniaceae.

\section{Conclusion}

The revision of the chromosome numbers previously reported for Bignoniaceae, allied to previous phylogenetic studies for the family, support a basic haploid chromosome 
number different from 20 for the family. The most likely primary base number for the family is $x=18$, which is the most common haploid number among its basal lineages. Ascending disploidy leading to $x=20$ is consistent with the chromosome numbers found in the most derived and diversified lineages, where that number predominates. A broad study involving reconstructions of chromosome counts in families related to Bignoniaceae, as well as in all of its clades, would help clarify the evolution of the karyotype of the family.

The chromosomes of the Tabebuia alliance showed only $\mathrm{GC}$-rich bands $\left(\mathrm{CMA}^{+} / \mathrm{DAPI}^{-}\right)$located in telomeric or proximal regions. The banding pattern within that clade was more variable than seen in Jacaranda, but less variable than in Bignonieae. Despite the intermediate level of variation observed, heterochromatin banding patterns offer a promising tool for distinguishing species, especially in the morphologically complex genus Handroanthus.

\section{Acknowledgments}

We thank the Conselho Nacional de Desenvolvimento Científco e Tecnológico (CNPq) and the Coordenação de Aperfeiçoamento de Pessoal de Nível Superior (CAPES) for financial support, and the Instituto Nacional do Semiárido (INSA) for their technical support.

\section{Conflict of Interest}

The authors declare no conflict of interest.

\section{Author Contributions}

JMPC perfomed the research, MK contributed karyotypic evolution and taxonomic identifications, LGS contributed with cytogenetic analysis and karyotypic evolution, LPF advised the research. All authors contributed to the analysis of the results and to the writing of the manuscript.

\section{References}

Acosta MC, Moscone EA and Cocucci AA (2016) Using chromosomal data in the phylogenetic and molecular dating framework: karyotype evolution and diversification in Nierembergia (Solanaceae) influenced by historical changes in sea level. Plant Biol 18:514-526.

Alcorcés de Guerra N (2002) Cariología de dos especies del gênero Tabebuia Gomes (Bignoniaceae). UDO Agrícola 2:4-21.

Almeida CCS, Carvalho PCL and Guerra M (2007) Karyotype differentiation among Spondias species and the putative hybrid umbu-cajá (Anacardiaceae). Bot J Linn Soc 155:541-547.

Almeida EM, Wanderley AM, Nollet F, Costa FR, Souza LGR and Felix LP (2016) A new species of Ameroglossum (Schrophulariaceae) growing on inselbergs in Northeastern Brazil. Syst Bot 41:423-429.

Alves MF, Duarte MO, Oliveira PE and Sampaio DS (2013) Self-sterility in the hexaploid Handroanthus serratifolius
(Bignoniaceae), the national flower of Brazil. Acta Bot Brasilica 27:714-722.

Barros e Silva AE, Marques AS, Karla GB and Guerra M (2010) The evolution of CMA bands in Citrus and related genera. Chromosome Res 18:503-514.

Berjano R, Roa F, Talavera S and Guerra M (2009) Cytotaxonomy of diploid and polyploid Aristolochia (Aristolochiaceae) species based on the distribution of CMA/DAPI bands and 5S and 45S rDNA sites. Plant Syst Evol 280:219-227.

Bittencourt Jr NS and Moraes CIG (2010) Self-fertility and polyembryony in South American yellow trumpet trees (Handroanthus chrysotrichus and H. ochraceus, Bignoniaceae): a histological study of postpollination events. Plant Syst Evol 288:59-76.

Carvalho R, Soares-Filho WS, Brasileiro-Vidal AC and Guerra M (2005) The relationships among lemons, limes and citron: a chromosomal comparison. Cytogenet Genome Res 109:276282.

Castro JP, Medeiros-Neto E, Souza G, Alves LIF, Batista FRC and Felix LP (2016) CMA band variability and physical mapping of $5 \mathrm{~S}$ and $45 \mathrm{~S}$ rDNA sites in Brazilian Cactaceae: Pereskioideae and Opuntioideae. Braz J Bot 39:613-620.

Chen ST, Zhou ZK, Guan KY and Nakata M (2004) Karyomorphology of Incarvillea (Bignoniaceae) and its implications in distribution and taxonomy. Bot J Linn Soc 144:113-121.

Chiarini FE, Santiñaque FF, Urdampilleta JD and Las Peñas ML (2014) Genome size and karyotype diversity in Solanum sect. Acanthophora (Solanaceae). Plant Syst Evol. 300:113-125.

Cordeiro JMP, Almeida EM, Lima SAA, Assis FNM, Souza LGR and Felix LP (2016a) Bignoniaceae, Bignonieae. In: Marhold $\mathrm{K}$ and Kucera J (eds) IAPT/IOPB chromosome data 23. Taxon 65:1455-1458.

Cordeiro JMP, Lima SAA, Paz SN, Santos MAS and Felix LP (2016b) Karyotype evolution in the genus Jacaranda Juss. (Jacarandeae, Bignoniaceae): chromosome numbers and heterocromatin. Genet Mol Res 15:gmr15048973.

Cordeiro JMP, Kaehler M, Souza G and Felix LP (2017) Karyotype analysis in Bignonieae (Bignoniaceae): chromosome numbers and heterochromatin. An Acad Bras Ciênc 89:26972706.

Evtushenko EV, Levitsky VG, Elisafenko EA, Gunbin KV, Belousov AI, afár J, Doleel J and Vershinin AV (2016) The expansion of heterochromatin blocks in rye reflects the co-amplification of tandem repeats and adjacent transposable elements. BMC Genomics 17:337.

Figueredo A, Oliveira ÁWL, Carvalho-Sobrinho JG and Souza G (2016) Karyotypic stability in the paleopolyploid genus Ceiba Mill. (Bombacoideae, Malvaceae). Braz J Bot 39:10871093.

Firetti-Leggieri F, Costa IR, Lohmann LG, Semir J and Martins ERF (2011) Chromosome studies in Bignonieae (Bignoniaceae): the first record of polyploidy in Anemopaegma. Cytologia 76:185-191.

Firetti-Leggieri F, Lohmann LG, Alcantara S, Costa IR and Semir J (2013) Polyploidy and polyembryony in Anemopaegma (Bignonieae, Bignoniaceae). Plant Reprod 26:43-53.

Fischer E, Theisen I and Lohmann LG (2004) Bignoniaceae. In: Kadereit JW and Kubitzki K (eds) The Families and Genera of Vascular Plants. Springer, Berlin, pp 9-98.

Gentry AH (1980) Bignoniaceae - Part I. Tribes Crescentieae and Tourrettieae. Flora Neotrop Monograph 25:1-131.

Gentry AH (1992) Bignoniaceae - Part II. Tribe Tecomae. Flora Neotrop Monograph 25:1-370. 
Gentry AH and Morawetz W (1992) Jacaranda. In: Gentry AH (ed) Bignoniaceae - Part II. Tribe Tecomae. Flora Neotrop, Monograph 25:51-105.

Goldblatt P and Gentry AH (1979) Cytology of Bignoniaceae. Bot Not 132:475-482.

Grabiele M, Debat HJ, Scaldaferro MA, Aguilera PM, Moscone EA, Seijo JG and Ducasse DA (2018) Highly GC-rich heterochromatin in chili peppers (Capsicum-Solanaceae): a cytogenetic and molecular characterization. Sci Hortic 238:391399.

Grose SO and Olmstead RG (2007) Taxonomic revisions in the polyphyletic genus Tabebuia s. 1. (Bignoniaceae). Syst Bot 32:660-670.

Guerra M (1986) Reviewing the chromosome nomenclature of Levan et al.. Braz J Genet 9:741-743.

Guerra M (2000) Patterns of heterochromatin distribution in plant chromosomes. Genet Mol Biol 23:1029-1041.

Guerra M (2008) Chromosome numbers in plant cytotaxonomy: Concepts and implications. Cytogenet Genome Res 120:339-350.

Guerra M (2012) Cytotaxonomy: The end of childhood. Plant Biosyst 146:703-710.

Machado MC, Carvalho PCL and van den Berg C (2015) Domestication, hybridization, speciation, and the origins of an economically important tree crop of Spondias (Anacardiaceae) from the Brazilian Caatinga dry forest. Neodiversity 8:8-49.

Marinho ACTA, Vasconcelos S, Vasconcelos EV, Marques DA, Benko-Iseppon AM and Brasileiro-Vidal AC (2018) Karyotype and genome size comparative analyses among six species of the oilseed-bearing genus Jatropha (Euphorbiaceae). Genet Mol Biol 41:442-449.

Mehrotra S and Goyal V (2014) Repetitive sequences in plant nuclear DNA: Types, distribution, evolution and function. Genomics Proteomics Bioinformatics 12:164-171.

Moore RJ (org) (1974) Index to plant chromosome numbers for 1972. Regnum Veg 91:1-108.

Morawetz W (1982) Morphologisch-ökologische Differenzierung, Biologie, Systematik und Evolution der neotropischen Gattung Jacaranda (Bignoniaceae). Denkschriften der Österreichischen Akademie der Wissenschaften. Springer Verlag, Wien.

Oliveira IG, Moraes AP, Almeida EM, Assis FNM, Cabral JS, Barros F and Felix LP (2015) Chromosomal evolution in Pleurothallidinae (Orchidaceae: Epidendroideae) with an emphasis on the genus Acianthera: Chromosome number and heterochromatin. Bot J Linn Soc 178:102-120.

Olmstead RG (2013) Phylogeny and biogeography in Solanaceae, Verbenaceae and Bignoniaceae: A comparison of continental and intercontinental diversification patterns. Bot J Linn Soc 171:80-102.

Olmstead RG, Zjhra ML, Lohmann LG, Grose SO and Eckert AJ (2009) A molecular phylogeny and classification of Bignoniaceae. Am J Bot 96:1731-1743.

Olsen RT and Kirkbride Jr JH (2017) Taxonomic revision of the genus Catalpa (Bignoniaceae). Brittonia 69:387-421.

Ortolani FA, Mataqueiro MF, Moro JR, Moro FV and Damião Filho CF (2008) Morfo-anatomia de plântulas e número cromossômico de Cybistax antisyphilitica (Mart.) Mart. (Bignoniaceae). Acta Bot Brasilica 22:345-353.

Pessoa E, Felix LP and Alves M (2014) A new Epidendrum (Laeliinae Orchidaceae) from the Atlantic Forest of northeastern Brazil: Evidence from morphology and cytogenetics. Brittonia 66:347-352.

Piazzano M (1998) Números cromosómicos em Bignoniaceae de Argentina. Kurtziana 26:179-219.

Piazzano M, Las Peñas ML, Chiarini F and Bernardello G (2015) Karyotypes and DNA content in Bignoniaceae. Caryologia 68:175-183.

Raven PH (1975) The bases of the Angiosperm phylogeny: Cytology. Ann Missouri Bot Gard 62:724-764.

Refulio-Rodriguez NF and Olmstead RG (2014) Phylogeny of Lamiidae. Am J Bot 101:287-299.

Roa F and Guerra M (2012) Distribution of 45S rDNA sites in chromosomes of plants: structural and evolutionary implications. BMC Evol Biol 12:225.

Saze H (2018) Epigenetic regulation of intragenic transposable elements: a two-edged sword. J Biochem 164:323-328.

Scaldaferro MA, Grabiele M and Moscone EA (2012) Heterochromatin type, amount and distribution in wild species of chili peppers (Capsicum, Solanaceae). Genet Res Crop Evol 60:693-709.

Schweizer D (1976) Reverse fluorescent chromosome banding with Chromomycin and DAPI. Chromosoma 58:307-324.

Stiefkens LM, Las Peñas ML, Bernardello G, Levin RA and Miller JS (2010) Karyotypes and fluorescent chromosome banding patterns in southern African Lycium (Solanaceae). Caryologia 63:50-61.

Van-Lume B and Souza G (2018) Cytomolecular analysis of species in the Peltophorum clade (Caesalpinioideae, Leguminosae). Braz J Bot. DOI: 10.1007/s40415-018-0449-9.

Van-Lume B, Esposito T, Diniz-Filho JAF, Gagnon E, Lewis GP and Souza G (2017) Heterochromatic and cytomolecular diversification in the Caesalpinia group (Leguminosae): relationship between phylogenetic and cytogeographical data. Perspect Plant Ecol Evol Syst 29:51-63.

\section{Internet resources}

Lohmann LG and Ulloa CU (2016) Bignoniaceae. In "Checklist of the World," MOBOT/NYBG/Kew Gardens. iPlants prototype Checklist, http://www.iplants.org/ (accessed 10 April 2018).

Uthscsa. Image Tool (IT) - Version 3.0, http://ddsdx.uthscsa.edu/dig/download.html (10 April 2014)

\section{Supplementary material}

The following online material is available for this article: Table S1 - Chromosome numbers recorded for the Bignoniaceae family and their respective bibliographic references.

\section{Associate Editor: Marcelo Guerra}

License information: This is an open-access article distributed under the terms of the Creative Commons Attribution License (type CC-BY), which permits unrestricted use, distribution and reproduction in any medium, provided the original article is properly cited. 